\title{
A History of the Washington, DC Intellectually Disableds'Use of the Judiciary in their Forty-Year Battle for Habilitation: Social versus Medical-People versus Profit
}

\author{
Toby Terrar* \\ City University of Los Angeles, USA
}

Submission: April 28, 2017; Published: July 27, 2017

*Corresponding author: Toby Terrar, City University of Los Angeles, 15405 Short Ridge Ct, USA, Tel: 301-598-5427; Email: tobyterrar@aol.com

\begin{abstract}
Abbreviations: IQ: Intelligence Quotient; DDA: Developmental Disabilities Administration; SRA: Social Rehabilitation Administration; TANF: Temporary Assistance for Needy Families; CLF: Continuing Legal Education; AISP: Annual Individual Support Plan; ULS: University Legal Services; PADD: Protection and Advocacy for Individuals with Developmental Disabilities; P\&A: Protection and Advocacy; DDS: Department of Disability Services; AMH: Anchor Mental Health; Assertive Community Treatment (ACT); CPEP: Comprehensive Psychiatric Emergency Program; SDM: Suppprted Decision-Making; QT: Quality Trust; HCBS: Home and Community-Based Services; SYEP: Summer Youth Employment Program; SSI: Supplemental Security Insurance ; ARC: Association for Retarded Citizens
\end{abstract}

\section{Introduction}

This essay summarizes the intellectually disableds' history of defending their habilitation rights in the Washington, D.C. courts over the past forty years. It focuses in particular on their fight against the city government as part of their effort to obtain a social-economic model of habilitation that guarantees them job security. Their fight has included resistance to the city's medical (Medicaid) model, in which psychotropic and seizure medicine is, in their view, used to dampen their quest for substantive habilitation. The study begins with the 1970s when the current medical versus social conflict got its start.

\section{Attorney Oversight}

In 1976 the District of Columbia's intellectually disabled filed a civil law suit, Evans et al v. Washington, against the city in U.S. District Court [1]. In that suit they sought the court's help to remedy the District's long-standing failure to protect them. The federal court in the "First Evans Consent Decree" upheld the claims of the disabled [2]. This resulted in the city enacting "The Mentally Retarded Citizens Constitutional Rights and Dignity Act of 1978" (hereafter 1978 Act) [3]. It was renamed in 2006 as "The Citizens with Intellectual Disability Act" [4].

By way of background, psychologists using standardized intelligence quotient (IQ) tests define the intellectually disabled as that $3 \%$ of the population who score two standard deviations below the statistical mean [5]. By this definition DC, with a population of 670,000 in 2016 , has 20,000 intellectually disabled [6]. The DC government's Developmental Disabilities Administration (DDA) provides services to about $10 \%$ or 2,250 of them, which includes the 600 surviving Evans plaintiffs [7]. The others are helped by their families, public schools and the DC Social Rehabilitation Administration (SRA). The latter includes Temporary Assistance for Needy Families (TANF) and services for alcoholics, drug-addicts and public offenders [8].

The 1978 Act provided that the DC Superior Court oversee the habilitation of those disabled who had been civilly committed as wards of the city. The Act defined commitment as follows: "Commitment" means the placement in a facility, pursuant to a court order, of an individual who has at least a moderate intellectual disability at the request of the individual's parent or guardian without the consent of the individual [9].

The Act also included a provision that each of them have assigned a permanent attorney to advocate for them in their dealings with the DC government [10]. The attorney provision was requested by the disabled. Their advocate Michael Perlin summarizes the reason for the request: The record of the legal profession in providing legal advocacy services to mentally disabled person has been grossly inadequate. Before the early 1970 s, court hearings were infrequently required prior to the 
ordering of involuntary civil commitment, counsel was rarely provided, and courts regularly defaulted in their decisionmaking responsibilities. The historical critique was unanimous:

Traditional, sporadically-appointed counsel were unwilling to pursue necessary investigations, lacked expertise in dealing with mental health problems, and suffered from "rolelessness," stemming from near total capitulation to experts, hazily defined concepts of success/failure, inability to generate professional or personal interest in the patient's dilemma, and lack of a clear definition of the proper advocacy function. As a result counsel functioned "as no more than a clerk, ratifying the events that transpired, rather than influencing them" [11]. Voicing the interest of the disabled for the permanent attorney system was President Carter's Commission on Mental Health's Task Force on Legal and Ethical Issues. In 1978 it recommended passage of legislation "which would establish and adequately finance a system of comprehensive advocacy services for mentally handicapped persons" [12].

The logic of having permanent attorney oversight ran along several lines. First, just as in a criminal commitment, when a person comes under the state's control, rights are curtailed, such as habilitation choices about employment, family, housing, education and medication. The lawyer aids the disabled to mitigate the curtailment. Secondly, from the perspective of the disabled, commitment means that the state comes under their (the disableds) control. Their court-appointed lawyer helps fight against the city's attempts to escape this control. In discussing the DC Code's definition of commitment, John Connelly, who is the former legislative director of the Information, Protection and Advocacy Center for Handicapped Individuals, Inc., explained this interpretation: But even a cursory reading of the Act reveals the word to be an obligation and abiding promise from the District to protect its vulnerable citizens, not as the agency would have one believe, some kind of restrictive, rights-denying internment [13].

The Superior Court judiciary has generally assisting the disableds' attempts to control the city by interpreting the 1978 Act in an expansive manner. Illustrative of the expansive interpretation of the Act in protecting the disabled was Superior Court Gladys Kessler's remarks in a 1984 case, "The mental retardation statute is a remedial and expansive law, and should be liberally construed in furtherance of its benevolent purposes"[14]. Similar were Superior Court Magistrate Judge Diane M. Brenneman's comments in a 2006 case. After explaining that the 1978 Act presumed high expectations concerning the disableds' habilitation, she wrote:

The controlling statute here is the Mentally Retarded Citizens Constitutional Rights and Dignity Act ("the Act"), which is remedial in nature because its purpose was and still is to eliminate violations affecting mentally retarded citizens of the District of Columbia. It has long been recognized that remedial statutes warrant liberal construction and interpretation to assure that the purposes of the statute are achieved and that the interests of the protected class are preserved. The Act is a remedial statute because it arose from a history of abuses of mentally retarded citizens of the District of Columbia, which came to light in the still-on-going case of Evans v. Williams, 206 F.3d 1292 (D.C. Cir. 2000). In Court, a history of the District of Columbia government's responsibility in abusing and neglecting respondents, over-medicating, beating and burning individuals committed to the District's mental retardation system came to light [15].

In compliance with the attorney provision of the Act, the DC Superior Court currently contracts with 25 lawyers who are paid $\$ 90$ per hour from funds provided by the federal Criminal Justice Act [16]. The court rules mandate that the attorneys act as the judiciary's eyes and ears in enforcing habilitation rights [17]. These rights extend not only to food, clothing and shelter but to protecting and improving their lives concerning physical fitness, medication, active programming, gainful employment, communications and speech, independent living, family involvement and social and religious activities [18]. In performing their duties the attorneys are required to attend continuing legal education (CLE) programs in order to make use of the ever-evolving programs available to the clients.

On a day-to-day basis the attorneys are part of the individual's support team and advocate for their wishes in the development of the annual Individual Support Plan (ISP). It sets out in writing and in detail how the team will support the individuals. The ISP reviews the progress of the past year and establishes the goals and plans for the coming year. As part of their monitoring duties, the attorneys on a quarterly basis visit the clients at their residence and day program, which includes reviewing the medical and activity books to assure compliance with the ISP goals.

The lawyers also advocate at annual court reviews that are held for each of the disabled and at any other court hearings during the year, if problems develop that need the judge's help [19]. In preparation for the court reviews the attorneys file a status report, which discusses the clients' progress and any areas that are of concern. When the clients are in the hospital, the attorneys visit them more frequently in order to monitor the care and compliance with the ISP. The disabled are more vulnerable in the hospital because they are not familiar with the routine and the hospital staff is not familiar with the special needs of the disabled. The attorneys help prepare written protocols that are posted in the clients' medical chart and on the walls of his hospital room.

\section{City Resistance to Oversight}

As noted, the attorney oversight system was forced on the city as the result of its having lost in the Evans litigation. Before and after the loss, as the Evans judge complained, the city tended not to acknowledge its neglect and over the years resisted the courts, including seeking D.C. City Council legislation in 2002, 2009, 
2016 and 2017 to divest Superior Court and the court-appointed attorneys of jurisdiction [20]. Among the city's arguments against oversight is that commitment of the disabled to the city deprives the disabled of their liberty. However, the disabled and their advocates, such as Joel Curtis, have maintained that the main liberty which the city seeks is its own liberty to take a minimalist interpretation of the 1978 Act [21]. The attorneys working for the judiciary, being federally funded, rather than by the DC City Council, act independently from the city's minimalism [22].

In countering the minimalists' argument against attorney oversight, law school professor Michael L. Perlin echoes the complaint of the disabled, that legal rights are not self-executing and that where there is a lack of attorney representation, the government has historically inflicted harm [23].

He writes: The declaration by a court of a right "to" a service or a right to be free "from" an intrusion does not in se provide that service or guarantee freedom from intrusion. A right is only a paper declaration without an accompanying remedy and, without counsel (so as to best guarantee enforcement), there is little chance that the rights "victories" that have been won in test case and law reform litigation in this area will have any impact on the mentally disabled population [24].

In addition to its libertarian argument attorney oversight, the DC government has suggested that University Legal Services (ULS) can provide the disabled with adequate attorney protection [25]. An example of this argument was made in a 2015 statement by the director of the DC Department of Disability Services to the DC City Council: University Legal Services is the designated protection and advocacy agency for the District of Columbia, established under the "Developmental Disabilities Assistance and Bill of Rights Act." It receives federal funding to operate the Protection and Advocacy for Individuals with Developmental Disabilities (PADD) program, authorized by federal law to help District of Columbia residents with developmental disabilities exercise their full rights as citizens [26].

The response of the disabled and their allies concerning the ULS-type Protection and Advocacy (P\&A) programs was voiced by Professor Michael Perlin [27]. He pointed out that the legislative history of the P\&A Act specifies that it was not Congress's intention to authorize P \& As to regularly provide assistance to individuals but was conceived of as a mechanism to litigate class action suits to prevent institutional-wide neglect and abuse [28]. As he puts it, P\&A programs are neither able nor expected to redress individual issues and government policy directives stipulate that P\&A money should generally not be used for individual cases but rather, it is the function of the state to pay for individual representation [29].

In addition to its attempts at the City Council to eliminate court-appointed attorneys, the city for the last decade has pursued another minimalist strategy. It has by-passed the 1978 Act's mandate to make new admittees to the disability system known to the court. This prevents the court from appointing an attorney to the disabled and eliminates the court's mandate to determine if the person is competent and if the admission is voluntary [30].

Superior Court Judge Gladys Kessler has discussed the legislative history of the court's role in determining the voluntariness of "voluntary admission" to the city's services. She writes that the 1978 Act mandated a court review "to prevent the 'voluntary' admission of individuals who are 'coerced' by 'parents who are tired of taking care of them into saying they want to be admitted to an institution" [31]. Illustrative of the problem caused by the city's bypassing of the judiciary is the case of VR. In 2007 the DC Department of Disability Services (DDS) admitted her to their intellectual disability services without notifying the court. She has a dual diagnosis-both mental health and intellectual disability.

As VR explained it, because she did not voluntarily take medication or go to a day program, the contractor to which she was assigned, Anchor Mental Health (AMH), had a medical guardian appointed. When she refused to go to the contractor's office to obtain a Haldol injection every third Friday, the organization's Assertive Community Treatment (ACT) team filed a missing persons report with the police. The police would then go to her apartment, handcuff her and take her to the Comprehensive Psychiatric Emergency Program (CPEP). There she was threatened with commitment at St. Elizabeths Mental Hospital if she did not "consent" to the medication. VR's admission to such DDS services, in her opinion, is not voluntary. She complains that the practice of a DC contractor calling out the police and having her arrested without probable cause gives her less rights than a common criminal [32]. But from the government's perspective, the police are merely part of her "Supported Decision-Making" (SDM).

There is also a third strategy the city follows for evading attorney monitoring, besides DC Council legislation and failing to notify the court of new admittees. This strategy involves the city's use of pliable professionals to upgrade a person's IQ level, so that the person becomes ineligible for habilitation. The D.C. Code $\S$ 7-1303.04 authorizes commitment only if the individual has at least a moderate intellectual disability, both cognitively and adaptively [33]. Illustrative of where the city was recently foiled in its manipulation strategy is the D.C. Court of Appeals case, In Re Karen Perry [34]. The disabled as represented by advocate Pierre Bergeron obtained a judgment that a person could not be discharged from commitment without being provided a trial to contest the up-graded IQ. The court also ruled that the disabled could obtain the help of a psychologist who was not on the city's payroll [35].

\section{Fiscal Minimalists}

Behind the city's resistance to attorney monitoring, as argued by the disabled and as will be elaborated on shortly, is the DC Board of Trade, its vote-grafting Medicaid contractors and Quality Trust (QT), which was established in 2001 as a by- 
product of a $\$ 31$ million dollar settlement. The money which the city was forced to pay to the disabled in the Evans case and which is now depleted, was used to set up QT to monitor and advocate for the disabled. However, from its inception, QT contracted with the city and received funding from other city contractors. Not surprisingly, it took a minimalist view of habilitation rights. Typically, during the city's 2009 campaign to eliminate Superior Court monitoring, QT worked on the side of the city while seeking $\$ 500,000$ from the city to set up a reduced monitoring system to replace the Superior Court judiciary [36,37].

Concerning QT's actions, the Evans judge questioned the wisdom of replacing with QT employees the Superior Court system. The judge observed that the Superior Court system was spending \$2.8 million from the US Congress for the advocacy of lawyers independent of the city's economy influence. In the judge's view using QT as a protector would amount to putting the monitoring onto the disabled themselves. The judge commented:

It is troublesome to me to have-you [QT] are on the side of amicus for the plaintiffs [the disabled] and then I see this legislation which is inconsistent with court supervision, which is Ms. Efros' [city government] legal argument, the District can do it themselves. And your argument is that the individuals [the disabled] should be thought to do it themselves [38]. The judge went on to describe the difficulties she herself had with a wellfinanced monitoring team, in protecting just 600 Evans plaintiffs, and yet QT with fewer resources was seeking to protect 1,400 individuals or perhaps the entire 29,000 disabled population [39].

During the 40-year course of the Evans litigation, which ended in 2016, and which paralleled the Superior Court oversight, the presiding Evans judge routinely was in agreement with the plaintiffs' (the disabled) complaints that the city was neglecting to delivery basic necessities which resulted in deaths and hospitalizations that the government's own investigators found preventable [40]. Nevertheless, the Evans judge, from the perspective of the disabled, followed a fiscally minimalist interpretation of the 1978 statute, viewing it as extending not much beyond food, clothing and shelter [41]. In contrast the disabled argued for a continuum of support, which included not only home and community-based habilitation, but a full-service city institution such as Forest Haven that provided gainful employment via city-owned farms and factories [42].

Following its minimalist interpretation, the Evans court sided with a dozen other jurisdictions in pushing toward replacing their state-run institutions with privately-contracted habilitation [43]. The annual cost in recent years per disabled in the unionized state-owned institutions that still exist is about $\$ 200,000$ [44]. The cost of privatized intermediate care facilities (ICF) using non-union staff is $\$ 85,000$ [45]. The cost of Medicaid Home and Community-Based Services (HCBS) waiver facility with little or no staff is $\$ 34,000$ [46].
A majority of the DC disabled are now in the minimalist HCBS system, which from their view maximizes the city's neglect. Medicaid mandates that if a state takes part in Medicaid, and all the states now take part, they have to provide, besides medicine, minimum services, including food, clothing and shelter. But those that receive services under the HCBS waiver are not covered under the mandate to receive basic necessities [47]. They receive medicine from Medicaid, but they obtain their necessities under other federal programs including Supplemental Security Insurance (SSI), Section 8 Rental Housing, Food Stamps and TANF [48]. This means that during economic crises, such as occurred following the 2008 recession, their necessities are terminated [49]. The conservatives balance the budget not by increasing taxation on themselves to make up for reduced revenue, but by forcing the disabled into shelters and homelessness.

Even in non-crisis periods the necessities for decades have been rationed for those not under the Medicaid mandate. In 1998 Robert Downs, president of DC Arc, commented on a national study that 271,000 persons with intellectual disability were on waiting lists for community-based services and supports. About DC's waiting list problem for housing, personal assistance, transportation, respite care and employment training he observed: We have a complete disconnect between the expectation of the Citizens of the District of the real need. We believe the citizens are saying, "why ask for services when we're not going to get them anyway?" That unfortunately has been keeping our numbers down and without data to substantiate an ongoing need for expansion of services; it has been relatively easy for the government to ignore the problem of un served individuals with mental retardation by suggesting that there are only isolated incidents of unmet needs [50]. Despite the Evans and Medicaid minimalism, the disabled and their Superior Court advocates have defended as noted, an expansive interpretation of the 1978 act, arguing that it protects their rights concerning economic habilitation. A summary of the disableds' habilitation thinking will help explain their differences with the city government.

\section{Habilitation}

From the perspective of the disabled, habilitation equates with gainful work at a living wage so that they can raise families in security like the non-disabled [51]. Their view of habilitation is summarized by Terry Carroll. He was director of the National Institutes on Rehabilitation and Health Services (NIRHS) between 1960 and 1971. NIRHS was a federally-funded, labor union-backed advocacy organization. Carroll wrote: The principle element in a national habilitation and health program is a full employment program that would provide socially useful, non-hazardous jobs at a living wage to every worker. One of the first steps toward achieving such a program would be the repeal of the 1947 Taft-Hartley Act and its sequel, the Landrum-GriffinKennedy Act and an anti-union NLRB [National Labor Relations 
Board], which have impeded workers' efforts to unionize and obtain fair working conditions and wages [52].

From the disabled standpoint, what the DC government has attempted over the years to offer them and to their direct caregivers is permanent poverty. Illustrative of the disableds thinking about jobs was a 2012 report prepared by the University Legal Services Protection and Advocacy Program (ULS), which organization was one of their defenders in the Evans case. It documented how DC's intellectually disabled in large numbers seek gainful work, but the government gives them a near-zero work option [53].

The report summarized: Regardless of where ULS presented, whether it was a day program, prevocational program, or supported employment program, ULS heard repeatedly from individuals that they want to work. Nevertheless, these individuals encounter a myriad of obstacles to employment... Some individuals are told over and over again that they are not ready for work. They are told this by providers and representatives of DDS [DC Department of Disability Services]. This seems to be true nationwide. One study found that "state and federal policy do not consistently prioritize employment." It also found that community rehabilitation providers have not reallocated resources to community employment [54].

It is of interest that during certain periods in the preMedicaid era, the DC government was more helpful in providing employment. This help included the early era of Forest Haven, which was a residential institution for the intellectually disabled at Laurel, Maryland between 1925 and 1991, the Occoquan Workhouse for a century until it closed in the 1970s, the DC unit of the Works Progress Administration (WPA) in the mid-1930s, the World War II full-employment era and over the last 30 years the Mayor's Summer Youth Employment Program (SYEP) and the Job Corps [55]. [Graphic 1 (p. 11) "Fight or Starve" (1930)].

\section{Medical Model}

While the city in the past has sometimes taken an expansive view of habilitation rights, since the 1970s its dealings with the disabled have been dominated by the federal Medicaid program and fiscal conservatism [56]. Instead of supporting a labor model of habilitation and jobs, as Terry Carroll above summed up, the medical model tends to label disability as pathological and the disabled as helpless [57]. The parallel policy of fiscal conservatism has meant, in the words of city historians Harry Jaffe and Tom Sherwood, that the government "kept the city's social service budget low, held down local taxes, and applied taxes to construction projects at the behest of the white business community" [58].

The conservative program from the 1970s until it was closed in 1991, focused on starving Forest Haven and its employment habilitation, while replacing its unionized (American Federation of State, County and Municipal Employees/AFSCME) and Civil-
Service protected work force with contractor-owned group homes staffed by at-will workers. The disabled in opposing the Forest Haven shut-down argued that privatization and union liquidation would turn one of their biggest assets, their directcare staff, into their biggest liability [59].

The non-union work force that would take over would be unskilled and little motivated because it had none of the government protections existing for workers in other professions, such as the eight-hour day, forty-hour work-week protection of the FLSA, the union protections of National Labor Relations Act, or the protections of the Family and Medical Leave Act and DC workers compensation statutes [60]. The result would be a constant staff turnover. The city would engage the lowest-bidding, most politically-connected contractors, who would make their profit by underpaying and over-working these individuals [61]. [Graphic 2 (p. 13) Central Labor Council Foster godparents march (5-13-76); Graphic 3 protest May Day parade (5-13-76)].

One of the scholarly advocates who have verbalized the opposition of the disabled to the city's privatization of direct care staff is American University law professor Daniela Kraiem. She commented on what she calls the city's exploitation of the impoverished disability direct-care workers, which both paralleled and was part of its neglect of the disabled:

An autonomy paradigm-even one deeply rooted in human rights-that rests on a system in which women of color and family caretakers receive wages and benefits so low that they themselves are eligible for public benefits, with little or no health and safety regulations despite dangerous working conditions, is ultimately not rooted in social justice. For a progressive movement based on human and civil rights principles, ignoring the worker on the other side of the equation should not be possible. Much like we cannot countenance a feminism blind to the injustices of race and class. I argue that we should not ground a movement for the rights of persons with disabilities in the exploitation of others, especially when those others are overwhelmingly low-income women of color and low-income female members of all races [62].

Spearheading the conservative's deinstitutionalization strategy, as Jaffe and Sherwood indicate, were the Washington Board of Trade-connected disability contractors, their big law firms and their lobby group, the DC Association for Retarded Citizens (ARC), whose director was Vincent Gray [63]. Initially they also sought to split the intellectual disability program off from the Department of Human Resources (DHR) in order to give themselves more influence over the disability budget.

At the national level the conservatives had the support of politicians like Ronald Reagan who used libertarian "freedom" and "fiscal conservatism" ideology to justify the replacement of the country's public habilitation facilities with homelessness and 
prisons [64]. As one advocate put it, the deinstitutionalization program against the disabled had influence in both parties and was a "sibling" to the drive to privatize Social Security, to privatize public education with vouchers, to replace free higher education with school loans and to substitute "consumer directed" insurance company dominated health care for free universal healthcare [65].

Habilitation advocate Terry Carroll criticizes the privatizers' fiscal argument: I hope you will consider the paradox presented by any proposed system which would be socially funded and privately delivered, with the mistaken assumption that avarice is a motivating factor that inevitably leads to efficiency [66].

\section{Medication}

As noted, in place of a labor approach to habilitation and jobs, the conservatives offered the medical model, that is, medication. This has been a nationwide problem going back to the 1960s. In the 1976 Forest Haven Congressional Hearings, there was testimony that $50 \%$ of the residents were already being given psychotropic drugs as a substitute for adequate funding of habilitation.

About the drugging abuse the following exchange took place at a Congressional hearing in 1976 between the DC Congressional Committee chair, Charles Diggs and the Forest Haven superintendent, Roland Queene: Mr. Dellums. It is your perception that 50 percent is a rather substantial percentage of the clientele? Where psychoactive medication is administered to them, what percentage of that is used because of the need to restrain patients because of inadequate staff or are all of these instances therapeutic or can they be justified on therapeutic ground?

Mr. Queene. Many of our residents have very serious health problems and they fall into the profound and the severe levels of retardation. Therefore they require considerable medication. Certainly to admit that these-this kind of program, that the medical involvement here is one in which we want to control residents, is not one that I am particularly fond of.

Certainly there may be situations-and I think there are very few, really - where we have to use drugs to control.

Certainly when we reach a point where we have to do something like that, that resident is referred to D.C. General or it sent to St. Elizabeths. But as you pointed out earlier, there are some people that are inappropriately placed at Forest Haven whose problems are not mental retardation but are either emotionally disturbed or have some other physical problem. Therefore, I think that the drug problem is not as intense as you alluded to it; we are not using it as a way to control our residents [67].

Disability activists responded to the drug abuse with a provision in the 1978 Constitutional Rights and Dignity Act that outlawed the overuse of medication. It read, "All customers have a right to be free from unnecessary or excessive medication. Medications shall not be used as a punishment for the convenience of staff, as a substitute for programs, or in quantities that interfere with the customer's habilitation program" [68].

Despite the statute, the disabled and their judiciary advocates have maintained that the medication is systematically used as a type of chemical straightjacket to restrain resistance to their meaningless lifestyle [69]. As such, the drugging, it is argued, also violates their First Amendment right to speech. It locks them into a prison without appearing to do so. It prevents them from speaking spontaneously, taking initiative and voicing their demands, preoccupations and preferences. They are, as one of them put it, submerged in a sweet indifference, divorced from their environment by an invisible partition [70].

In resisting medication abuse over the years, the disabled have maintained in their Superior Court litigation that acting up against the neglect of their overwhelmed staff is not a psychotic or seizure disorder [71]. An anti-drug abuse scholar noted that "diagnostic approaches are imperfect and imprecise even when done by the most qualified psychiatrists; misdiagnosis may be as high as fifty percent" [72]. Disability advocate Peter Breggin called it "medicating normality" [73].

In his view, to be anxious, depressed or rebellious when not allowed to have a job and family is a realistic response. Another scholarly ally, Rory Sheehan, found that at the international level, using a study of 33,000 intellectually disabled adults, some $71 \%$ of those being drugged do not have the kind of serious mental or seizure illness for which the drugs are designed [74]. The judge in the Evans case, while not taking an expansive view about habilitation, repeatedly attacked the government's psychotropic medication program for not having an overall treatment plan, counseling, therapeutic strategies for coping without drugs or efforts to wean the disabled off the drugs [75].

From the view of the disabled, their drug problem stemmed mainly from the city's addiction to the pharmaceutical industry and insurance-dominated Medicaid system, which reimburses money for medication, not habilitation. Out of this comes the tendency to misdiagnosis and, as the courts have documented, having a medication rate for the disabled at twice that of those not under contractor care. In a 2010 Evans "Opinion," the judge remarked that a random survey of the disabled in group homes and apartments found 19 of 37 receiving one or more psychotropic drugs [76]. The city-funded Quality Trust, using a larger sample, found that 71\% (162 of 228) of the disabled were being prescribed psychotropics [77]. While $50-70 \%$ of the disabled in group homes and apartments are drugged, the rate in the general population for mind-altering medicine is $20 \%$ [78]. [Graphic 4 (p. 19).

Evans intellectual disability plaintiff R.H.: End stage medication abuse results in skeleton demineralization (osteoporosis), loss of muscle tissue, quadriplegia, permanent 
fetal posture, bed sores, agranulocytosis (lowered white-blood cell count, causing vulnerability to infection) and "death by natural causes."]. Besides their fight against over-medication, the disabled use the courts to defend themselves against other medical-related abuses. For example, from the beginning of the Medicaid program in the 1970 s and over the next several decades, some 1,800 "elective surgeries" were done on the disabled against their will [79].

Their judicial resistance to the forced procedures included a series of cases in the 2000 s dealing with abortions. In one of these cases, Does I Through III v. District of Columbia, the DC Federal District Court Judge, Henry Kennedy, ruled in 2005 in favor of three women, two of whom had been forced to have abortions. He stated that the government's involuntary abortion policy violated their due process right to refuse medical treatment [80]. The city had argued that undertaking an inquiry into the wishes or interests of an individual with intellectual disability was an impossible charge. To this the judge responded that such an argument "offended both common sense and the dignity of retarded citizens" [81]. The court ordered the government to obey its legal obligation to undertake an inquiry as to the wishes of the disabled.

Unfortunately from the women's perspective, a more conservative Federal Appellate Court in 2007 overturned the 2005 decision, ruling that the city could forcibly abort them. To this decision law professor Catherine Blackburn objected that the appellate court was over-ruling the common law which respected the right of competent persons to make wrong or unwise decisions concerning health, or simply to differ with their health providers on the best course of action. Blackburn wrote, "The common law has long recognized that only the individual experiences disease; only the individual experiences the effects of treatment for that disease; and only the individual can choose between the effects of disease and the effects of treatment" [82].

\section{Labor Model}

The disabled and their judicial advocates maintain that the city since the 1970s in dealing with the disabled as a medical problem has ignored their need for labor habilitation [83]. Illustrative is their Georgetown University defender, Professor Maurice Jackson, who documents in a study of the problem that only 20 percent of a DC citizens' habilitation has to do with medicine; the bulk of habilitation is determined, as he puts it, by social-economic factors such as employment, family and education $[84,85]$. The failure of the city to provide this, in Jackson's words, is a "structural or institutional injustice." Supporting Jackson is disability scholar James Baker. He points out that the failure to provide employment habilitation and the resulting poor health is a national problem. He writes:

Our nation's public health systems largely focus on the prevention of disability rather than on preventive health services for people with disabilities. As a result of this bias. Americans with disabilities are on the whole, in poor health. Again, systemic barriers rather than the medical impairment itself define the disability experience. Many factors contribute to the poor state of health among Americans with disabilities. People with disabilities are less likely to be employed, more likely to live in poverty, less likely to participate in the social fabric of their communities, and, unless they quality for Medicaid or Medicare benefits, less likely to have health insurance coverage [86].

Besides Jackson and Baker, another academic, Daniela Kraiem, similarly complains that "Capitalism has no role for the elderly and people with disabilities. They are non-productive" [87]. From this perspective the disabled and their advocates, socialism better meets their needs. As Bernie Sanders put it in his 2016 presidential bid, socialism focuses on people rather than profit [88].

In the court system the disabled argue, as noted earlier, that in the city's pre-Medicaid era, their habilitation at various times centered on labor, including gainful employment at DC-owned farms and in DC-owned textile, furniture and other factories at Occoquan, Lorton and Laurel. The DC and federal government gave their factories exclusive contracts to produce clothing, furniture, upholstery and other goods for the city's hospitals, schools, vehicles and office buildings [89].

The earlier habilitation was, as UCLA historian Jennifer Uhlmann comments, similar to that in the socialist countires [90]. The planned labor-shortage in those countries made labor costs high, giving workers strength against management. As the academic advocate David Lane summarizes, because there was no capital under the socialist model, there was no incentive to increase the profit of capital by reducing labor costs or the number of workers employed [91]. [Graphic 5 (p. 23) DTS sewing, Times Herald (11-27-1942)].

In their judicial advocacy, the disabled, as in the 2007 D.C. Superior Court case of "B.G," maintain that their right to labor habilitation involves more than merely earning money [92]. One of their defenders writes, "This right is not granted because of materialistic-social consideration, but rather from the point of view that work is an essential condition for personality development and the formation of specific personality characteristics" [93]. In their view, if they are now helpless, it has more to do with the medical model than with their diagnosis [94].

Similarly, in pointing to the medical model as an obstacle to their unemployment, the disabled and their judicial advocates tend to reject intelligent quotient (IQ) testing [95]. They maintain that the majority of those labeled as disabled receive that designation because of the poverty into which they are born, not because of organic, intrauterine or early lesions of the central nervous system that result in a tendency not to progress and low IQ scores. As the medical scholar John Wing summed up, because of their full employment economy and resulting lack of poverty, 
the Soviets had little "psychosocial" intellectual disability [96]. Eliminating poverty in his view eliminated most disability.

Of interest concerning job advocacy and rejection of IQ testing is the work of the academic Joseph Wortis. He contrasts the lack of IQ testing in the socialist world with the 1930s eugenic approach, which in his view is synonymous with the medical model and which puts a burden on the disabled by labeling them, using psychometric testing and low IQ scores [97]. According to the eugenic views, a two standard deviation from the IQ median, as noted earlier, results in a disability label, which equates with $3 \%$ of the population. In the Soviet system because they did not test, there were no low IQ scores [98].

The disabled in their court advocacy have contended that DC's Forest Haven educational program in the pre-Medicaid era was correct in focusing on vocational schools and training youth for employment from an early age, no matter what their diagnosis [99]. Their ally, the educator Jean Nazzaro explains how early training in the social model prevents attitudinal and motivational problems that otherwise overshadow the original disability:

To put a child in a situation where he is exposed to failure, even at the preschool or kindergarten level, is to set things up so that other problems, attitudinal problems and motivational problems, may soon overshadow the original problem of retardation. They feel it is very necessary to protect the child and help him develop the best functioning level he can with the resources he has and not allow any opportunity for the secondary kinds of emotional problems to develop. The earlier they can pick him up in a special program, the more protected he is from these complications, and the more directly they can get to his retardation and begin to work on it [100]. [Graphic 6 (p. 25) DTS Farming Star (8-20-1943)].

Another advocate also emphasizes that job training starting in infancy maximized working capacity in the city's early Forest Haven era [101]. During the 1920s and 1930s a system of habilitation units, training centers, vocational guidance units, and prophylactic workshops in the city-owned factories and farms that operated like those in the socialist world [102]. From the medical perspective, which the medical professional John Wing reflects, the social model is too "paternalist," too protective of habilitation rights. He comments: The very thoroughness of the service must carry a certain disadvantage. It would require a deeper knowledge of Russian life and custom than I possess to assess how far a certain gentle but insistent paternalism and over-protectiveness is characteristic throughout the whole society. It is plainly evident in attitudes to the mentally retarded. In many cases it brings good results; probably the more severe the handicap the more satisfactory the system [103-109].

\section{Conclusion}

This essay has outlined the history of D.C.'s intellectually disabled over the past 40 years in seeking employment habilitation and in resisting the neglect of the city and its Medicaid-dominated contractors. The history is relevant in their battle against the city's current attempt in the DC City Council to eliminate the habilitation oversight jurisdiction of D.C. Superior Court. The mayor in leading what is in effect the DC Board of Trade's fight to restrict the disabled' Constitutional rights claims she is seeking to restore their rights. The answer to her demagogy is a review of the history. The disabled for 40 years have found the city to be the enemy of their rights. The courts have been their ally against the city. What the disabled want from the City Council is gainful employment and an end to being drugged-up, not an attack on their judicial allies.

\section{References}

1. Evans v. Washington, 459 F. Supp. 483 (D.D.C. 1978), began in 1976 in the Federal District Court and continued until 2016, being renamed a number of times, including Evans v. Kelly, 979 F.2d 248 (1992); Evans et al v. Fenty, 480 F. Supp. 2d 280 (2007) and Evans et al v. Bowser, DC Federal District Court, Civil Action 76-CV-00293. The case was patterned after a 1972 New York case, New York ARC v. Rockefeller. The New York case ended with a consent judgment that committed New York state to seek "community placement" for the 5,000 residents at the Willowbrook State School in Staten Island, New York, USA.

2. Joy Evans (1978) Evans v. Washington, 459 F. Supp at 484. USA.

3. D.C. Official Code $\S 7-1301.01$ et seq. (2012 Repl. and 2016 Supp) The Citizens with Intellectual Disabled Act (D.C. Law 2-137), Columbia.

4. (2007) The People First Respectful Language Modernization Act of 2006. Colombia.

5. Duane FS (2003) The Disability Rights Movement: From Deinstitutionalization to Self-Determination. University Press of America, USA, pp. 12-13.

6. (2016) The DC Code § 7-1301.03(19) (2012 Repl. and 2016 Supp) does not use IQ scores in defining intellectual disability, but rather focuses on functional factors. It defines intellectual disability as: Mental retardation or mentally retarded means substantial limitation in capacity that manifests before 18 years of age and is characterized by significantly sub average intellectual functioning existing concurrently with 2 or more significant limitations in adaptive functioning.

7. Laura Nuss (2012) The Work Options for Individuals with Intellectual Disabilities: The Obstacles and the Possibilities. WashingtonDC, USA, p. 34 .

8. United State (1976) Forest Haven [microform]: joint oversight hearings before the Subcommittee on Education, Labor, and Social Services and the Committee on the District of Columbia, House of Representatives, Ninety-fourth Congress, second session, on legislative and oversight jurisdiction over Forest Haven, District of Columbia institution for the mentally retarded. USA, p. 292.

9. § 7-1301.03. Definitions, Columbia.

10. D.C. Code § 7-1304.02 Representation by Counsel. Columbia.

11. Michael LP (1992) Fatal Assumption: A Critical Evaluation of the Role of Counsel in Mental Disability Cases. 16(1): 39-59.

12. US President's Commission on Mental Health. Task Panel on Legal and Ethical Issues (1978) Mental Health and Human Rights: Report of the Task Panel on Legal and Ethical Issues. Ariz Law Rev 20(1): 49-174.

13. John C (2015) Don't Reduce Rights for Disabled People. Washington Post, USA. 
14. Judge Gladys Kessler (1984) In the Matter or Andre Brooks, 112 Daily Wash. L. Rep, No. 37 Part 1.

15. Diane MB (2006) Memorandum Opinion. In the Matter of JJ Sup. Ct MR Nos 611-682, p. 3.

16. (2012) DC Code $\S 11-2601$ et seq. The maximum the court pays per disabled per year is $\$ 1,500$, unless a waiver to spend more is obtained. Columbia.

17. (2005) Superior Court Rules of Mental Retardation Procedure (D.C. SCR-MR, Washington, DC: DC Rules Annotated, Matthew Bender \& Co., 1985, 2005). Rules 5-7: 301-305.

18. Connelly. Don't Reduce Rights p. C-4.

19. Ibid (2009) The Developmental Disability Reform Act of 2009 Bill 18501. Washington DC, Columbia.

20. Joel C (2016) Letter to DC City Council Members. In: Neha Patel, Letter to Joel Curtis (manuscript in possession of author p. 1.

21. DC Code § 11-2601 et seq (2012 Repl). On the judiciary's federal funding, see DC Code $§ 11-2601$ et seq. (2012 Repl.). Columbia.

22. Perlin ML (1992) Fatal Assumption: A Critical Evaluation of the Role of Counsel in Mental Disability Cases. 16(1): 39-59.

23. Perlin ML (1992) Fatal Assumption. p. 47.

24. (1996) ULS has been DC's Protection and Advocacy (P\&A) agency.

25. Laura N (2015) Letter to Yvette Alexander, Chair of the DC Council's Committee on Health and Human Services.

26. 42 USC $\S \S 10801$ et sec (1988) Protection and Advocacy Act.

27. ULS produced studies concerning the city's institutional-wide abuses in the area of over-drugging and lack of employment habilitation, USA.

28. Perlin ML (1992) Fatal Assumption. pp. 54-55.

29. DC Code § 7-1303.02. Voluntary Admission. Columbia.

30. Gladys K (1985) In Re Bicksler, Columbia.

31. VR (2015) Transcript of Interview. p. 4.

32. DC Code § 7-1303.04 (2016) Petition for commitment of individual 14 years of age or older filed by parent or guardian. Columbia.

33. In Re Karen Perry (2017) DC Court of Appeals, No. 15-FM-180.

34. Peter JN (2010) In Re AT. (DC Court of Appeals, 2010)10: FS 124.

35. McElhatton J (2012) Thompson's Ties to Politically Active Businesses Confirmed. The Washington Times, USA.

36. Evans (2009) Transcription hiring of Motion hearing before the honorable ellen segal huvelle. Washington, DC, USA, pp. 153-154.

37. Ibid. p. 151.

38. John Connelly (2009) Testimony submitted to the dc council's committee on human services concerning B18-0501. Columbia, p. 4.

39. Evans (2015) Transcript of Status Hearing Civil Action 76-CV-00293 DC. Columbia, pp. 17-19.

40. Perlin ML Fatal Assumption. p. 55.

41. Terrar T (2016) Why the Intellectually Disabled in the Evans Case Continue to Hold the DC Government Neglectful. International Journal on Disability and Human Development 16(2): 1.

42. Anonymous (2009) Deinstitutionalization Toolkit: Institutions - in Brief.

43. Ibid. p. 3 .
44. Cynthia S (2006) Rebalancing Long-Term Care: The Role of the Medicaid HCBS Waiver Program. National Health Policy Forum, USA, p. 16.

45. IMary BM (2017) Medicaid Restructuring Under the American Health Care Act and Nonelderly Adults with Disabilities.

46. Musumeci and Foutz (2017) Medicaid Restructuring Under the American Health Care Act and Nonelderly Adults with Disabilities. pp. 1- 9 .

47. Brad Plumer (2013) Food stamps will get cut by $\$ 5$ billion this week and more cuts could follow. Food-stamps-will-get-cut-by-5-billionthis-week-and-more-cuts-could-follow. In: Erin Graves (Ed) Rooms for Improvement: A Qualitative Metasynthesis of the Housing Choice Voucher Program Housing Policy Debate (2016) 26: 346-361.

48. The DC Code $\S \S 7-1305.01$ (a) \& (b) (2001) states that funding for Medicaid-waiver-type programs is given only To the extent that appropriated funds are available to carry out the purposes of this chapter." It is the disabled and their relatives who are the safety net. The D.C. Code § 7-1303.11 (2001) declares (1) that a person with an intellectual disability, or the father, mother, spouse, or adult child of the person shall pay to the District the costs of habilitation, care, or both, if one of those parties, or the person's estate is able to pay; 2) that any person liable for such costs who does not pay them shall be issued a court citation and may be ordered to pay; and (3) that the Mayor may examine any of the parties under oath to determine their ability to pay.

49. Robert Downs (1998) DC Arc Push for Waiting Lists, APP Update (Washington, DC: DC Arc, Inc. Advocacy and Public Policy Division, June 1998), issue 1, p. 3. See also, Connelly, Testimony Submitted to the DC Council's Committee on Human Services, pp. 5-6.

50. The DC Code section 7-1301.03(14) (2001) defines habilitation as follows: Habilitation means the process by which a person is assisted to acquire and maintain those life skills which enable him or her to cope more effectively with the demands of his or her own person and of his or her own environment and to raise the level of his or her physical, intellectual, social, emotional and economic efficiency. Habilitation includes, but is not limited to, the provision of community-based services.

51. Toby Terrar (2013) A Biography of Terence Evan Carroll: WorkingClass Health Care Advocate. Journal of Alternative Medicine Research (New York: Nova Science Publishers, Inc. 2013) 5(3): 205-216.

52. Brown (2011) The Work Options for Individuals with Intellectual Disabilities, p. 25, writes: In D.C. in the 2011 fiscal year, the vast majority of individuals receiving both RSA [Rehabilitation Services Administration] and DDA services (332 or 355) did not achieve an employment outcome through RSA. Only 23 individuals entered or retained any type of employment. Ibid pp 20-21.

53. (2016) DC's positive history of meeting the disableds' emploment needs is summarized in Toby Terrar, Why the Intellectually Disabled in the Evans Case Continue to Hold the DC Government Neglectful After Forty Years: A History of Differing Views about Disability Rights. International Journal on Disability and Human Development (National Institute of Child Health and Human Development in Israel, 15(4): 2-12.

54. The Medicare Bill (Public Law 89-97, 79 Stat. 286, 89th Congress, H.R. 6675, July 30, 1965, codified as 42 USC ch 7 was enacted as an amendment to the Social Security Act of 1935. The bill was known as Title XVIII. Also passed at the same time was Medicaid or Title XIX. The latter provided federal matching funds to states in order to assist, among others, the senior intellectually disabled that were at or near the poverty-line. DC and the state governments administer the program, following federal guidelines. Since 2001 the Centers for Medicare and Medicaid Services agency (CMS) under the US Dept of Health and Human Services, sets the guidelines. The federal financial 


\section{Global Journal of Intellectual \& Developmental Disabilities}

contribution averages 60 percent, with DC putting up 40 percent. The guidelines require DC to run a medical care advisory committee which oversees the development of new policies and any changes in Medicaid administration. Currently Medicaid covers 42 million Americans, 9 million of whom have disabilities.

55. In 1972 Congress expanded Medicaid eligibility to include younger Americans (under 65) who have permanent disabilities. In the same year Congress enacted another program, Supplemental Security Income (SSI), which provided a guaranteed income to, among others, the intellectually disabled. See Kevin Bozic, Medicare and its Evolution to 2011 in Manish K. Sethi and William H. Frist, eds., An Introduction to Health Policy: A Primer for Physicians and medical Students New York, USA,18: 29-30.

56. Richard Eyman (1987) Life Expectancy and Mental Retardation points out that intellectual limitation is not unhealthy (Washington, DC: American Association of Mental Deficiency pp. 2-3.

57. Harry Jaffe and Tom Sherwood (1994) Dream City: Race, Power and the Decline of Washington, DC (New York: Simon \& Schuster, 1994) p. 28. In: Terrar Why the Intellectually Disabled in the Evans Case Continue to Hold the DC Government Neglectful p. 12.

58. (1976) Among those who helped in the resistance against the conservatives was the national organization, Voice of the Retarded" (VOR), as well as their AFSCME-represented, direct-care workers. They sponsored research, organized politically, managed public relations, and participated in litigation. See Speaking Out for People with Intellectual Disabilities \& Mental Retardation, VOR, US Congress, Forest Haven: Joint Oversight Hearings (1976) p. 122.

59. The Greater Washington Central Labor Council, AFL-CIO gave its help by establishing a foster-grandparent program in which 55 trade union families established an "adult-child" relationship with Forest Haven youth who had no parent. Fair Labor Standards Act Pub L 75718: 676 .

60. USC ch 8 In 1974 domestic workers came under federal wage and hour protection, but this did not include paraprofessional home health workers, home-care workers or companionship workers See 29 C.F.R. $§ 552.6$ (2010). In addition employees of businesses with fewer than 15 workers were excluded from the act's Title VII coverage. See 42 U.S.C. $§ 2000$ e (b) (2006). Employees of businesses with under 50 workers were also excluded from FMLA coverage. See 29 U.S.C.A. § 2611(2)(b)(ii) (2010); likewise all in-home employees were excluded. See 29 U.S.C. § 152(3) (2006). The scholars Charles P. Sabatino and Simi Litvak in Liability Issues Affecting ConsumerDirected Personal Assistance Services-Report and Recommendations Elder LJ (1996) 4(2): 247. at 289, Peggie R. Smith in Aging and Caring in the Home: Regulating Paid Domesticity in the Twenty-First Century 92 Iowa L. Rev. 1835, 1857 (2006), and Hila Shamir in Between Home and Work: Accessing the Distributitive Effects of Employment Law in Markets of Care, 30 Berkeley J Emp \& Labor L 404-460 (2009), have documented the exploitation of homecare workers by the various labor and employment laws.

61. (2012) University of Michigan law school professor, Samue Bagenstos in "The Past and Future of Deinstitutionalization Litigation 34 Cardozo Law Review 1-52 discusses the turnover and low-pay aspects of privatization: Jobs in state institutions have typically been unionized in this country, while most jobs in community programs have not. Community programs are generally run not by the state itself but by private non-profit or for-profit agencies that contract with the sate. Those private agencies are rarely unionized, and they typically pay substantially less (and have much greater turnover) than the state does for work in its institutions. Indeed, unions have found it exceptionally difficult to organize the small, decentralized, often non-profit and faith-based agencies that provide community services.

62. Steven J Taylor (2008) The Direct Support Workforce Crisis: Can Unions Help Resolve this? (2008) available at Roger J. Stancliffe, K Charlie Lakin, John R. Shea, Robert W. Prouty \& Kathryn Coucouvanis,
The Economics of Deinstitutionalization, in Costs and Outcomes of Community Services for People with Intellectual Disabilities. In: Roger J Stancliffe, Charlie Lakin K (Eds) 289,295 Nari Rhee \& Carol Zabin, Aggregating Dispersed Workers: Union Organizing in the Care Industries. Geoforum 40: 969.

63. Daniela Kraiem (2011) Consumer Direction in Medicaid Long Term Care: Autonomy, Com modification of Family Labor, and Community Resilience. American University Journal of Gender Social Policy and Law 19: 671-719.

64. Vincent Gray (1976) Testimony US Congress, Forest Haven: Joint oversight hearings to monitor the Evans decision, the court required the city to establish the office of The Developmental Disabilities Professional (DDP). In 1983 DC Arc, Inc. obtained an appointment to carry out the DDP responsibilities. It operated under the name of D.C. Arc Pratt Monitoring Program. From the disabled perspective, it equated their protection with protecting contractor profit. The disabled were a cash-cow. From this view, there was a conflict of interest in both monitoring contractors and being a multi-million dollar contractor. The ARC monitor stated the following contractororiented mandates in a 1996 list concerning the Evans court's Remedial Plan, which it had negotiated p. 176:

a. Reinforce the mandate to pay providers within 10 calendar days of receipt of an acceptable invoice.

b. Requires DHS or the CFO to submit monthly reports to the Court, Special Master and Court Monitor regarding Medicaid and MRDDA payments made.

c. Assign civil fines, payable to the Clerk of the Court for failure to pay.

d. Orders filed audits for ICFs every 3 years with desk audits in between

e. Assigns the Special Master Authority to hear and act on any claim from providers of nonpayment of acceptable invoices.

f. Requires the District to establish a process for the negotiation and final conclusion of at least annual contracts for all Evans class providers by $10 / 31 / 96$

g. Reinforces the 1:60 ratio case management ratio.Karen Clay Letter (Washington, DC: DC Arc, Pratt Monitoring Program, August 19, 1996 manuscript in possession author); see also, Anonymous, APP Update (Washington, DC: DC Arc, Inc. Advocacy and Public Policy Division, June 1998), issue 1, p. 2; Anonymous, "Return of Organization Exempt from Income Tax: IRS Form 990" (manuscript, in possession of author) (DC Arc, Inc. 2003, gross receipts $\$ 14,799,987$ ).

65. Samuel Bagenstos (2012) The Pastand Future of Deinstitutionalization Litigation. 34 Cardozo Law Review 34: 1-52.

66. Daniela Kraiem (2011) Consumer Direction in Medicaid Long Term Care: Autonomy, Commodification of Family Labor, and Community Resilience. American University Journal of Gender, Social Policy and Law 19: 671-719.

67. Kraiem Consumer Direction in Medicaid Long Term Care p. 696.

68. Terence Carroll, quoted in Terrar (2013) A Biography of Terence Evan Carroll p. 213. Yale professors Elizabeth Bradley and Lauren Taylor in The American Health Care Paradox: Why Spending More is Getting us Less (New York: Public Affairs, 2013), as quoted online at the-health-care-spending-paradox, accessed June 29, 2015, joined with Carroll in noting that the whole society pays more for less concerning habilitation: The United States faces a central paradox in its health-care system: we spend more than any other industrialized country on health, yet we rank among the lowest in many dimensions of health. Our health-care spending is more than 17 percent of our gross domestic product, nearly double the spending in many other industrialized countries. But we rank far below most of these same nations in measures of life expectancy, infant mortality, and maternal mortality, among other key statistics. The huge costs and poor outcomes are difficult for Americans to fathom. 


\section{Global Journal of Intellectual \& Developmental Disabilities}

69. Roland Queene (1976) Testimony US Congress, Forest Haven: Joint oversight hearings p. 90.

70. DC Code $\S 7-1305.05(\mathrm{~h})$ (2001) This provision was incorporated into the DC Department of Human Services policy guidelines. See Department of Human Services/MRDDA. "Use of Psychotropic Medications Policy Statement. p. 2

71. See Judge Linda K Davis (2007) Opinion In the Matter of JJ et al, Sup. Ct. MR Nos. 611-682 pp.27 33-37 (cases h, In re J.K., M.R. 10-90, case k, In re C.A., M.R. 27-95, case 1 In re D.E., M.R. 97-85, and case m"In re K.S., M.R. 225-82,), in which the disabled won favorable rulings against the city's use of drugs to restrain them.

72. Catherine Blackburn (1990) New Directions in Mental Health Advocacy? Clozapine and the Right of Medical Self-Determination. Mental and Physical Disability Law Reporter 14(5) 453-461.

73. See case n, In re MM, MR. 488-82-90. In: Davis Opinion. In the Matter of JJ et al, pp. 37-38.

74. Vicki Anderson (1984) Right to Refuse Antipsychotic Medication: A Proposal for Legislative Consideration. Indiana Law Review 17(4): 1035-1055. at pp.

75. Richard Ashcroft and Bill Fraser (2001) Are Antipsychotic Drugs the Right Treatment for Challenging Behavior in Learning Disability. Journal of Medical Ethics 27(5): 338-343.

76. Peter Breggin (2013) Psychiatric drug withdrawal: a guide for prescribers, therapists, patients, and their families. New York, USA

77. Stuart Kirk, Tomi Gomory, David Cohen, Mad Science: Psychiatric Coercion, Diagnosis, and Drugs Transaction Publishers, USA.

78. Rory Sheehan, et al., (2015) Mental Illness, Challenging Behavior, and Psychotropic Drug Prescribing in People with Intellectual Disability: UK Population Based Cohort Study. British Medical.

79. Ellen Segal Huvelle (2010) Opinion, Evans v. Bowser $2^{\text {nd }} 116$ Civil Action 76-CV-00293 (DC Federal District Court, Washington, DC June 1, 2010), pp. 37-38, quoting from the 2009 Special Masters' Report. In a 2009 Evans case review recorded in ibid, p. 45, the judge rebuked the government because a resident at a group home owned by Westview Medical and Rehabilitation Services, Inc. was being prescribed ten different psychotropic medications.

80. Ellen Segal Huvelle (2007) Opinion Evans v. Bowser (714 F. Supp. $2^{\text {nd }} 116 ; 2010$ U.S. Dist. LEXIS 55096), Civil Action 76-CV-00293 (D.C. Federal District Court, Washington, D.C.: June 1, 2010), pp. 1516, footnote 5, quoting Court Monitor's Quarterly Report (August 2 2007).

81. Quality Trust (2009) Monitoring Unit Annual Report and Data Summary: October 1, 2008-September 30, 2009 Washington, DC: Quality Trust of Individuals with Disabilities p.6.

82. JJ Stolker (2005) Psychotropic Drug Use in Intellectually Disabled Group-Home Residents with Behavioral Problems. Pharmacopsychiatry 35: 19-23, Anonymous America's State of Mind Report.

83. (2007) Illustrative of over-drugging is the Melonie Nelson case. She was a forty-one-year-old who choked to death from food and drugging in the kitchen of her group home in 2007. During the investigation Marshila Davis, an employee of D.C. Health Care, which operated Nelson's home, gave testimony. Davis had cared for Nelson several days prior to her death, but was on duty at another group home at the time of the death. A report of the drugging of Nelson, as set forth in Brendan Smith, "Scores of Deaths in DC Group Homes: The District and D.C. Health Care hit with \$15 million lawsuit over the tragic end to Melonie Nelson's life, Legal Times (Washington, D.C.: May 28, 2007), vol. 30 (blsmith@alm.com), stated: Davis says she last saw Nelson three days before her death when Nelson was so drugged up on medications she could barely walk... Nelson was prescribed nine different medications in the months before her death, according to a ULS report. A side effect from her psychotropic medications which could cause clenching and abnormal movement of the jaw may have increased her risk for choking.

84. (2005) Does I Through III v. District of Columbia, 232 F.R.D. 18 (D.D.C 2005); Does v. District of Columbia, 374 F. Supp. 2d 107 (D.D.C. 2005); Anonymous, Elective Surgery; MR; Substituted Judgment; Due Process, Mental and Physical Disability Law Reporter, American Bar Association 30(1): 24-30.

85. Ibid Blackburn New Directions in Mental Health Advocacy? p. 459.

86. For cases in which the disabled obtained judicial help for employment at Goodwill Industries (case b), Value Village (case g), the Department of Commerce (case j), and DC ARC (case o), see Davis, Opinion, In the Matter of JJ et al, Sup. Ct. MR Nos. 611-82 (case b In re JLH MR 596-82: 17-19; case g In re GR MR: 52-90: 25-26; case j, In re SH MR 250-81: 30-32; case o, In re BG MR 429-82: 38-40.

87. Maurice Jackson (2016) The Health of the African American community in the District of Columbia: Disparities and Recommendations Washington DC: Georgetown University School of Nursing \& HealthStudies p.3.

88. Ibid.

89. James P Baker, et al. (2008) The State of Disability in America: An Evaluation of the Disability Experience by Life Without Limits Project. United Cerebral p.19 state-of-disability-in-america-anevaluation-of-the-disability-experience-by-the-life-without-limitsprojec.original.pdf, , accessed June 29, 2015. Baker goes on to remark at ibid., that people with disabilities are more than two and half times as likely to be diagnosed with diabetes and experience higher rates of other chronic conditions. They are less likely to engage in leisuretime physical activity and other recommended health behaviors. For example, people with disabilities are more likely to smoke and have higher rates of obesity. They are less likely to have good dental health. About 28 percent report symptoms of depression, and when asked, people with disabilities are less likely to report being satisfied with their lives." Baker emphasizes that the nature of disability is not the reason why Americans with disabilities are in poor health. He writes at ibid., , "Most can or should live long healthy lives.

90. Daniela Kraiem (2011) Consumer Direction in Medicaid Long Term Care: Autonomy, Commodification of Family Labor, and Community Resilience. American University Journal of Gender Social Policy and Law 19: 671-719.

91. Bernie Sanders (2015) Our Revolution: A Future to Believe. In: Thomas Dunne (2016) Books, St. Martin's Press. Edward Yudelovich (2015) Stop Minimum Wage Exclusion of People With Disabilities," Disability Rights and the Class Struggle New York, USA.

92. Terrar Why the Intellectually Disabled in the Evans Case Continue to Hold the DC Government Neglectful After Forty Years pp. 6-7.

93. Jennifer Uhlmann (2007) The Communist Civil Rights Movement: Legal Activism in the US, 1919-1946 University of California at Los Angeles, USA, p. 6

94. David Lane (1987) Soviet Labour and the Ethic of Communism: Full Employment and the Labour Process in the USSR, Boulder, Colorado: Westview Press pp. 1-2.

95. See case o, In re BG, MR 429-82, in Davis, Opinion, In the Matter of JJ et al, pp. 38-39.

96. Klause P Becker, et al. (1985) Educational Rehabilitation of the Handicapped in the German Democratic Republic and in the United States: An Overview New York: Pergamon Press, p. 121.

97. Cynthia Shirk (2006) Rebalancing Long-Term Care: The Role of the Medicaid HCBS Waiver Program Washington DC: National Health Policy Forum, George Washington University, USA p. 13.

98. See case g, In re GR, MR 52-90, in Davis, Opinion, In the Matter of JJ. et al, pp. 25-26, where the court ordered therapy, not IQ testing, to solve work-related behavior problems. 
99. John K Wing (1974) Psychiatry in the Soviet Union. British Medical Journal 1: 433-436.

100. Joseph Wortis (1967) Mental Retardation, Science American Association for the Advancement of Science 155(3768): 1442.

101. Mariia Pevzner (1961) Oligophrenia: Mental Deficiency in Children John McLeish, Soviet Psychology: History, Theory, Content London.

102. Ibid (2014) Multiple studies have traced genocidal ideas about the disabled to the eugenics, literally good birth, movement in the first part of the twentieth century. The Rockefeller, Carnegie and other foundations financed eugenic campaigns. See Marilyn Singleton, The 'Science' of Eugenics: America's Moral Detour Journal of American Physicians and Surgeons 19(4): 151-159.

103. Edwin Black (2003) War Against the Weak: Eugenics and America's Campaign to Create a Master Race (New York: Four Walls Eight Windows, 2003), (following Darwinian theory, the Harriman railroad fortune was used to sterilize the disabled); Harry Bruinius, Better for All the World: The Secret History of Forced Sterilization and America's Quest for Racial Purity (New York: Knopf, 2006); Angela Franks, Margaret Sanger's Eugenic Legacy: The Control of Female Fertility (Jefferson, N.C.: McFarland, 2005); Edward Larson, Sex, Race, and Science: Eugenics in the Deep South (Baltimore: Johns Hopkins University Press, 1995); Philip Reilly, The Surgical Solution: A History of Involuntary Sterilization in the United States (Baltimore: Johns Hopkins University Press, 1991); Christine Rosen, Preaching Eugenics: Religious Leaders and the American Eugenics Movement (New York: Oxford University Press, 2004); Rosa Ehrenreich and Jamie Fellner, Beyond Reason: The Death Penalty and Offenders with Mental Retardation (New York: Human Rights Watch, 2001); Michael Manning, Euthanasia and Physician-Assisted Suicide: Killing or Caring? (New York: Paulist Press, 1998); Pabst Battin, Rosamond Rhodes and Anita Silvers, Physician Assisted Suicide: Expanding the Debate (New York: Routledge, 1998).

104. (2008) Among the feminist groups that lobbied in the earlier period for eugenic legislation, as documented by Mary Ziegler, in Eugenic Feminism: Mental Hygiene, The Women's Movement, and the Campaign for Eugenic Legal Reform, 1900-1935, Harvard Journal of Law \& Gender, 31(1): 211-236, were the National Federation of Women's Clubs, the Women's Christian Temperance Union, and the National League of Women Voters. Those who study black eugenic thought are the scholars Gregory Dorr and Angela Logan in "Quality, not Mere Quantity Counts: Black Eugenics and the NAACP Baby Contests, in Paul Lombardo (Ed.), A Century of Eugenics in America (Bloomington, Ind.: Indiana University Press, 2011), pp. 68-92. Dorr and Logan write that W.E.B. DuBois, Thomas Wyatt Turner and academics at Tuskegee, Howard and Hampton Universities believed, as DuBois put it, that only fit blacks should procreate to eradicate the race's heritage of moral iniquity. Some 28 states enacted laws to legitimize forced sterilization of the disabled. Those who dominated the DC government could not obtain a sterilization law, but starting in 1933 they commenced sterilizing, arguing that since it was not prohibited, it was legal. See Anonymous, Control Over Sterilization Practice Asked, The Washington Post, USA, p. 1.

105. (1986) This philosophy was embodied in the Soviet constitutions, which stated, USSR citizens are obliged to show concern for the upbringing of children, to prepare them for socially useful labor and to rear worthy members of a socialist society. See Salvatore Imbrogno, Family Policy in the Soviet Union," International Journal of Sociology of the Family Autumn, 16(2): 165-180.

106. Jean Nazzaro (1973) In Mental Retardation in the Soviet Union, Education and Training of the Mentally Retarded 8(3): 166-171.

107. (2008) Sally Quinn in Furious Improvisation: How the WPA and a Cast of Thousands Made High Art New York: Walker \& Co., writes that between 1929 and 1931, some fifteen thousand Americans visited the Soviet Union. John Wing in Psychiatry in the Soviet Union at 434 comments about what the Americans saw concerning the disabled: Many factories have special workshops for handicapped people- for example, a sewing machine factory in the neighborhood of No. 8 dispensary in Moscow has 300 handicapped people in such a shop, as well as providing sheltered conditions for other handicapped people within the open workshops. The standard of work required is, of course, very much higher in the open factories than in the sheltered workshops (though these have a much higher standard than our British day centers). For example, such workers need to be members of a trade union; they need sickness certificates if they wish to stay away from work. In addition, there are special factories with homes attached.

108. Wing, Psychiatry in the Soviet Union at 433.

109. Ibid (1967) However, from the perspective of the disabled, the social model is more about fraternalism than paternalism. Despite his anti-paternalism, Professor Wing endorsed and quoted the Soviet academic, Anton S. Makarenko (1888-1939), whose paternalist approach to habilitation emphasized the importance for the disabled of collective work during early childhood within the family as the path to employment success as an adult. Makarenko in The Collective Family: A Handbook for Russian Parents (Garden City, NY: Doubleday \& Co., 1967), p. xiii, wrote: Both parents and children engaging in tasks appropriate to their different abilities but always for the common good is necessary for training in later collective living. By observing the example of such cooperative labor and mutual respect, and by himself carrying his proper share of responsibility, the child gradually acquires self-reliance, moral integrity and social dedications.

\begin{tabular}{l} 
Your next submission with Juniper Publishers \\
will reach you the below assets \\
- Quality Editorial service \\
- Swift Peer Review \\
- Reprints availability \\
- E-prints Service \\
- Manuscript Podcast for convenient understanding \\
- Global attainment for your research \\
- Manuscript accessibility in different formats \\
( Pdf, E-pub, Full Text, Audio) \\
- Unceasing customer service \\
Track the below URL for one-step submission \\
https://juniperpublishers.com/online-submission.php \\
\hline
\end{tabular}

